\title{
Kampania profilaktyczno-edukacyjna jako forma profilaktyki uniwersalnej. Na przykładzie ogólnopolskiej kampanii „Bqqdźmy poszukiwaczami autorytetu"
}

\section{The Preventive and Educational Campaign as a Form of Universal Prevention: On the Example of the National Campaign "Let's be the Seekers of Authority"}

\begin{abstract}
ABSTRAKT
Artykuł podejmuje tematykę kampanii profilaktyczno-edukacyjnych jako wyzwania dla współczesnej profilaktyki społecznej. Po wprowadzeniu teoretycznym zostały scharakteryzowane warunki i formy profilaktyki uniwersalnej, omówiono specyfikę kampanii profilaktyczno-edukacyjnych, a następnie przedstawiono przykład kampanii „Bąźmy poszukiwaczami autorytetu", w którq autorka jest zaangażowana od poczq̨tku jej trwania. Podstawowym problemem badawczym jest pytanie: $\mathrm{Na}$ czym polega specyfika kampanii profilaktyczno-edukacyjnych jako formy profilaktyki uniwersalnej? Czym się charakteryzuje i jak przebiegała kampania profilaktyczno-edukacyina „Bqdźmy poszukiwaczami autorytetu"? Metodq badawczq jest analiza dokumentacji, która powstała $w$ wyniku realizowania zadań zwiqzanych $z$ omawianq kampanią. W analizie wzięto pod uwagę zwłaszcza dokumentację zwiqzana z przygotowaniami do kampanii, dane $z$ ewaluacji procesu oraz raport końcowy.
\end{abstract}

SLOWA KLUCZOWE kampania profilaktyczno-edukacyina, profilaktyka uniwersalna, profilaktyka społeczna, ewaluacja kampanii profilaktyczno-edukacyinej, kampania „Bqqdźmy poszukiwaczami autorytetu"

\section{KEYWORDS}

preventive and educational campaign, universal prevention, social prevention, the evaluation of prevention and education campaigns, the "Let us be the seekers of authority" campaign

SPI Vol. 22, 2019/3

ISSN 2450-5358

e-ISSN 2450-5366

DOI: 10.12775/SPI.2019.3.003

Nadesłano: 29.06 .2019 Zaakceptowano: 3.11.2019

Artykuły i rozprawy 
Wyniki badań można podzielić na dwa obszary: pierwszy dotyczy zjawiska kampanii profilaktyczno-edukacyjnych jako nowego wyzwania dla profilaktyki społecznej. Drugi obszar zwiqzany jest bezpośrednio z tematykq omawianej kampanii, a mianowicie: z koniecznościq zwrócenia uwagi społeczeństwa na to, kto jest wzorem osobowym dla młodych ludzi, jak w zwiq̨zku z tym kształtuje się ich tożsamość oraz relacje, kto jest dla nich ważny, u kogo moga szukać wsparcia, jak rodzice i nauczyciele młodzieży szkolnej postrzegaja siebie w roli autorytetów, jak kształtuja relacje ze dziećmi i uczniami. Na podstawie przeprowadzonych badań stwierdzono, że we współczesnej kulturze młodzieżowej, opartej w dużej mierze na funkcjonowaniu medialnym, konieczne jest wzmacnianie postawy autorytetu w rodzinie i w szkole oraz kształtowanie relacji młodych ludzi z osobami stanowiq̨cymi wzór osobowy. Celem niniejszego artykułu jest opisanie warunków i form profilaktyki uniwersalnej oraz prezentacja jednej z takich kampanii profilaktycznych.

\section{ABSTRACT}

The article addresses the subject of preventive and educational campaigns as challenges for contemporary social prevention. After the theoretical introduction, the conditions and forms of the universal prevention are characterized, the unique nature of preventive and educational campaigns was discussed, and then an example of the campaign "Let us be seekers of authority", in which the author has been involved since its inception, was presented. The basic research problem is the question: What is the specificity of preventive and educational campaigns as a form of universal prevention? What are the features and effects of the preventive and educational campaign "Let us be the seekers of authority"? The research method is the analysis of documentation, which was created as a result of the implementation of tasks related to the discussed campaign. The evaluation data and the final report were particularly taken into account.

The research results can be divided into two areas: the first concerns the phenomenon of preventive and educational campaigns as a new challenge for social prevention. The second area is directly related to the subject of the discussed campaign, namely: the need to draw the attention of the public to who is a personal model for young people, as well as their identity, relations, who is important to them, to whom they can look for support, as parents and school youth teachers perceive themselves as authorities, as they shape relationships with their children 
and students. On the basis of the research conducted, it was found that in contemporary youth culture, based largely on the functioning of the media, it is necessary to strengthen authority in the family and school and to shape the relationships of young people with people representing the personal model. The purpose of this article is to describe the conditions and forms of universal prevention and to present one of such prevention campaign.

\section{Wprowadzenie}

Profilaktyka społeczna jest interdyscyplinarną nauką ugruntowaną na pograniczu pedagogiki, psychologii, socjologii, nauk medycznych i prawnych, poruszającą tematykę zapobiegania indywidualnym i grupowym problemom człowieka, które wynikają z wewnętrznych i środowiskowych nieprawidłowości rozwojowych oraz nienormatywnych zachowań na każdym etapie życia. Z drugiej strony profilaktyka jest dziedziną praktycznego działania edukacyjnego, wychowawczego i wspierającego proces rozwoju człowieka oraz dojrzewania jego osobowości do takiego stadium, w którym podejmuje on decyzje zgodne $z$ ukształtowanym sumieniem oraz zasadami etycznymi i uniwersalnymi regułami moralnymi. Takie rozumienie profilaktyki uwzględnia kryteria podziału etapów rozwoju moralnego człowieka w zgodzie z koncepcją Lawrence’a Kohlberga. W związku z tym nadrzędnym celem działań profilaktycznych jest uprzedzanie sytuacji niosących ryzyko zaburzeń rozwojowych, chorób, uzależnień chemicznych i behawioralnych oraz innych patologii społecznych w taki sposób, by człowiek samodzielnie, wykorzystując swoje zasoby, potencjały i kompetencje podejmował decyzje o unikaniu zachowań ryzykownych. Mówiąc prościej oraz kierując się koncepcją czynników chroniących i czynników ryzyka, celem profilaktyki jest minimalizowanie i likwidowanie tych ostatnich, będących predyktorami zachowań problemowych i niebezpiecznych oraz wzmacnianie i budowanie nowych czynników chroniących, które układają się w parasol ochronny przed nieprawidłowym postępowaniem.

Ukierunkowanie na cele determinuje podział działań zapobiegawczych ze względu na poziom istniejącego ryzyka indywidualnego i społecznego. Przez ostatnich kilkadziesiąt lat dzielono profilaktykę 
zwykle na trzy poziomy. Początkowo, szeroko ją definiując, ustanowiono pierwszorzędowe, drugorzędowe i trzeciorzędowe działania profilaktyczne (Szymańska 2012: 34-37). Obecnie mówimy o profilaktyce uniwersalnej, selektywnej i wskazującej. Pierwszy podział był nieostry, ponieważ działania profilaktyki pierwszorzędowej dublowały się z działaniami wychowawczymi, a trzeciorzędowej z terapeutycznymi i resocjalizacyjnymi. Problemy związane z tą klasyfikacją nie tylko dotyczyły finansowania i spraw administracyjnych związanych $z$ profilaktyką, ale przede wszystkim wiązały się z tendencją do aplikowania grupom niskiego ryzyka programów przeznaczonych dla osób podejmujących zachowania ryzykowne.

Aktualnie obowiązujący podział profilaktyki, autorstwa Patrycji Mrazek i Roberta Haggerty'ego (1994), jest upowszechniany od początku XXI wieku. Od 2003 roku wprowadzono go na terenie USA, a od roku 2005 jest on upowszechniany na terenie krajów Unii Europejskiej, także w Polsce. Rozpoczynając od końca, można powiedzieć, że profilaktyka wskazująca kierowana jest do osób podejmujących zachowania ryzykowne, ale w takim stadium, które nie kwalifikuje się do terapii czy leczenia. Najważniejsza jest tu sprawna interwencja, w miarę możliwości szybkie reagowanie na czynniki ryzyka i próba niedopuszczenia do eskalacji negatywnych zachowań. Aktywności podejmowane w obszarze profilaktyki selektywnej adresowane są do osób narażonych na działanie czynników ryzyka, ale niepodejmujących zachowań ryzykownych. Ważne jest tu zrównoważone działanie na czynnikach chroniących i czynnikach ryzyka, by nie dopuścić do inicjacji problemu ani do pogłębiania się istniejących już czynników ryzyka.

Profilaktyka uniwersalna, najbardziej nas tu interesująca, kierowana jest natomiast do szerokiej rzeszy całej, niezdiagnozowanej populacji, w celu wzmocnienia odporności na zachowania ryzykowne, a tym samym ograniczanie zaburzeń, chorób, uzależnień i innych problemów społecznych. Według literatury przedmiotu najważniejsze na tym poziomie jest wzmacnianie czynników chroniących, w tym przekazywanie wiedzy o zagrożeniach i uczenie najważniejszych umiejętności psychospołecznych, niezbędnych do zapobiegania problemom, takich jak umiejętności komunikowania się, rozwiązywania problemów, nawiązywania i utrzymywania relacji z innymi, radzenia sobie ze stresem czy niedogodnościami emocjonalnymi 
(Szymańska 2012: 37) oraz w miarę możliwości wczesne działania profilaktyczne kierowane do każdej grupy wiekowej, kształcące postawy prozdrowotne oraz związane z pełnieniem ról społecznych, szczególnie dziecka, ucznia, rodzica, wychowawcy (Jankowiak 2017: 147). Dla praktyka takie informacje są jednak zbyt ogólnikowe, dlatego często bywa tak, że dzieci w przedszkolach dowiadują się o zbyt odległych dla nich zagrożeniach związanych z paleniem papierosów, a dzieci w wieku szkolnym zapoznawane są z tematyką dopalaczy, rodzajami przestępstw czy skutkami uzależnienia od alkoholu. Takie przekazywanie informacji w grupach niskiego ryzyka może mieć skutki przeciwne do zamierzonych, dlatego warto uściślić i dookreślić warunki profilaktyki uniwersalnej.

\section{Warunki i formy profilaktyki uniwersalnej}

Pierwszym warunkiem, wbrew dotychczasowym koncepcjom, jest rozeznanie i wstępne zdiagnozowanie grupy docelowej, szczególnie wtedy, kiedy prowadzone są programy profilaktyki uniwersalnej w szkołach, świetlicach środowiskowych, przy parafiach czy siedzibach organizacji pozarządowych. Ważna jest rozmowa lub wywiad swobodny z opiekunem grupy bezpośrednio biorącej udział w zajęciach profilaktycznych lub też rozeznanie środowiskowe, polegające na zebraniu informacji na temat funkcjonowania, potencjałów i problemów środowiska lokalnego. Ważne jest, by diagnoza była zróżnicowana i zrównoważona (pełna) pod względem zbierania danych. Warto nie tylko badać to, co negatywne, szczególnie w przypadku młodych ludzi. Jak pisze Krzysztof Ostaszewski, zmiana perspektywy patrzenia na młodzież związana z koncepcją pozytywnego jej rozwoju stawia badaczom wymagania polegające na konieczności zwrócenia uwagi na atrybuty takie jak: umiejętności psychospołeczne, pozytywne relacje z innymi, sukcesy szkolne i pozaszkolne, poczucie własnej wartości i inne (Ostaszewski 2014).

Drugim warunkiem profilaktyki uniwersalnej jest położenie nacisku na wspieranie odporności poprzez wzmacnianie czynników chroniących, a nie na przekaz informacji o samych tylko zagrożeniach. Czynniki chroniące, w przeciwieństwie do czynników ryzyka, są bowiem wysoce niespecyficzne, to znaczy, że większość z nich chroni przed całym spektrum zachowań ryzykownych. „Działają podobnie 
w stosunku do wielu zaburzeń i problemów (...). Uniwersalnym czynnikiem chroniącym jest na przykład silna więź z rodzicami, ich obecność w życiu dziecka, przebywanie w miłującej wspólnocie rodzinnej” (Wojcieszek 2013). Poza tym, do uniwersalnych czynników chroniących należą: praktyki religijne (uczestnictwo w obrzędach religijnych, wiara, zaangażowanie w rozwój życia duchowego), przekonanie o konieczności przestrzegania uniwersalnych wartości moralnych i zasad etycznych, konstruktywna, wspierająca grupa rówieśnicza, zainteresowanie nauką, sukcesy szkolne, posiadanie zainteresowań i hobby oraz dodatkowo wybrane umiejętności psychospołeczne (Wojcieszek 2013: 50). Ważne, aby w ramach profilaktyki uniwersalnej wspierać te właśnie komponenty budujące odporność wobec zachowań ryzykownych, a nie tylko przekazywać informacje o samych zachowaniach ryzykownych, specyfice uzależnień czy środkach psychoaktywnych.

Ostatnim warunkiem jest właściwe dobranie formy zajęć zapobiegawczych. Najpopularniejszymi są incydentalne, często jednorazowe wydarzenia mające charakter edukacyjno-wychowawczy, takie jak: wykłady profilaktyczne, warsztaty, pogadanki z ekspertami lub idolami młodzieży, teatr profilaktyczny, pikniki integracyjne lub rodzinne $\mathrm{z}$ odpowiednio dobranym tematem wiodącym oraz wszelakiego rodzaju konkursy wiedzy o zagrożeniach, plastyczne, muzyczne, literackie, sportowe i inne. Badania Państwowej Agencji Rozwiązywania Problemów Alkoholowych (PARPA) pokazują, że są to najmniej skuteczne działania i rzadko ewaluowane. Wynika $z$ tego, że nie można $\mathrm{z}$ całym przekonaniem stwierdzić, iż są to działania skuteczne, choć niewątpliwie mogą być atrakcyjne i relatywnie ekonomiczne. Drugą, bardziej profesjonalną formą oddziaływań profilaktycznych są programy, które ze względu na jakość opracowania merytorycznego i metodycznego możemy podzielić na rekomendowane i autorskie. Te pierwsze widnieją w bazie stworzonej przez powołany w 2010 roku Zespół Rekomendujący złożony z pracowników wspomnianej wyżej agencji, Krajowego Biura ds. Przeciwdziałania Narkomanii, Ośrodka Rozwoju Edukacji oraz Instytutu Psychiatrii i Neurologii w Warszawie (por. Programy rekomendowane 2009). Drugie natomiast, nie zawsze spełniające standardy systemu rekomendacji, tworzone są najczęściej przez zaangażowanych nauczycieli i wychowawców, psychologów i pedagogów lub innych ekspertów 
działających w organizacjach pozarządowych zajmujących się wychowaniem i profilaktyką. Innym kryterium podziału programów profilaktycznych jest podejmowana problematyka zachowań ryzykownych. Tu można wyróżnić programy zintegrowane, których celem jest zapobieganie kilku i więcej zachowaniom ryzykownym, oraz programy specjalistyczne, podejmujące tematykę jednego zachowania ryzykownego. Warto też zwrócić uwagę na kryterium czasowe, według którego rozróżnia się programy długoterminowe, najczęściej trzymiesięczne, sześciomiesięczne, roczne lub kilkuletnie oraz krótkoterminowe, kilkugodzinne, opisane między innymi w modelu „krótkiej interwencji profilaktycznej w grupie" (por. Wojcieszek 2013). Trzecią zaś, dopiero kiełkującą w naszym kraju formą profilaktyki uniwersalnej są kampanie profilaktyczne i profilaktyczno-edukacyjne. Można je zakwalifikować do szeroko definiowanych kampanii społecznych, których celem jest zwiększenie świadomości i wiedzy odbiorców na temat określonego problemu społecznego, ale też zmiana postrzegania, myślenia i postaw wobec tego problemu. Kampanie są formą przekazu treści profilaktycznych i zwrócenia uwagi szerszej części społeczeństwa na ważne obszary i problemy z perspektywy edukacyjnej. Do tej pory nie zbadano skuteczności kampanii profilaktycznych, natomiast wiadomo, że w sferze medialnej sama transmisja informacji może przynosić skutki odwrotne do zamierzonych.

\section{Specyfika i krótka historia kampanii profilaktyczno-edukacyinych w Polsce}

Informacji o kampaniach profilaktyczno-edukacyjnych próżno szukać w naukowej literaturze, choć badania prowadzone w ich ramach mogą być wykorzystywane dla zobrazowania pewnych zjawisk czy symptomów zachowań normatywnych i ryzykownych. Ze względu na powszechność i próbę dotarcia do jak największej liczby odbiorców trudno też mówić o naukowej specyfikacji treści zapobiegawczych. Jednak można opisać kilka elementów wyróżniających kampanię profilaktyczną. Pierwszym wyróżnikiem jest wykorzystanie internetu jako głównego narzędzia przekazu profilaktycznego oraz narzędzia badawczego w ewaluacji kampanii. Internet jest tutaj rozumiany jako przekaźnik, ale również jako przestrzeń społeczna, 
w której tworzy się nowa jakość egzystencji i funkcjonowania młodych ludzi.

Drugą cechą omawianych kampanii jest konieczność przyjęcia strategii jej tworzenia. Na samym początku, podobnie jak w programach profilaktycznych, należy określić wiodącą problematykę i grupy docelowe, szczególnie jeśli chodzi o dzieci i młodzież. Im dokładniejsze określenie potencjalnego grona odbiorców, tym lepiej można dostosować przekaz do określonych grup osób pozostających na różnych etapach rozwojowych i poznawczych. Następnym krokiem $\mathrm{w}$ tworzeniu strategii jest zawężenie oraz spopularyzowanie problematyki poruszanej w kampanii, co pozwala na dokładniejsze opisanie zjawisk oraz określenie pożądanych postaw i zachowań. Trzecim krokiem jest określenie celów kampanii, które powinny jasno nawiązywać do teleologii wychowania i profilaktyki zachowań ryzykownych. Kolejnymi etapami pracy nad kampanią jest opracowanie produktu, czyli treści i formy przekazu profilaktyczno-edukacyjnego, jego wycena, promocja oraz dystrybucja. Niezwykle ważna jest strona wizualna, która oczywiście powinna współgrać z treściami zawartymi w pakiecie kampanijnym, ponieważ to ona jest często pierwszym elementem, na który odbiorca zwraca uwagę. Jeśli zostanie on zainteresowany produktem w postaci ulotki, broszury, plakatu, zabawki, gry, zeszytu czy aplikacji, łatwiej będzie mu przyjąć treść przekazu.

Trzecią cechą kampanii profilaktyczno-edukacyjnych jest konieczność umiejscowienia tego przekazu w podstawie koncepcji i teorii profilaktycznych, a przynajmniej w obszarze paradygmatycznym, który wyznaczy sposób myślenia, wpłynie na formowanie głównych informacji, także dotyczących norm i wartości oraz będzie determinował całość działań związanych z kampanią. Ostatnią właściwością omawianych kampanii jest konieczność monitoringu działań oraz ewaluacji ilościowej i/lub jakościowej podjętych działań.

Warto wspomnieć, że pierwszą, zrealizowaną pod egidą agencji PARPA kampanią profilaktyczno-edukacyjną w Polsce była w 1996 roku "Sonda 21”, której cel polegał na prowadzeniu spotkań z młodzieżą oraz jej przebadanie metodą sondażu diagnostycznego. Zadano wtedy dwa pytania: (1) Czy byłbyś za wprowadzeniem w Polsce zakazu zakupu alkoholu przez osoby poniżej 21 roku życia? (2) Czy w swoim życiu rodzinnym doświadczyłeś przykrych sytuacji $\mathrm{w}$ związku $\mathrm{z}$ piciem alkoholu przez bliskich, o których trudno 
Ci będzie zapomnieć? Wyniki były zaskakujące, ponieważ aż 65\% w grupie 200 tysięcy uczniów w wieku od 13 do 17 roku życia zadeklarowało, że jest za podniesieniem do 21 roku życia granicy wieku uprawniającego do kupowania napojów alkoholowych. Efektem tej kampanii było powstanie „Komitetu 21” - stowarzyszenia działającego na rzecz podniesienia granicy wieku oraz uruchomienie „Poczty Zaufania" dla dzieci z rodzin z problemem alkoholowym.

Także w 1996 roku zrealizowano kampanię „Chrońmy młodość”, której celem było zwrócenie uwagi na łamanie prawa w dziedzinie sprzedaży alkoholu osobom nieletnim (PARPA 2019). Dwa lata później w całej Polsce pojawiły się plakaty informacyjne na temat bezpiecznych wakacji w ramach kampanii „Radość bez alkoholu wakacje bez ryzyka".

W ciągu kilkunastu ostatnich lat zrealizowano co najmniej kilkanaście zapadających w pamięć ogólnopolskich kampanii profilaktyczno-edukacyjnych, między innymi: „Znajdź czas dla swojego dziecka”, „Bliżej siebie - dalej od narkotyków” i inne, polegające głównie na tworzeniu bilbordów, plakatów, ulotek, spotów reklamowych emitowanych w telewizji i radiu. Ostatnią kampanią, realizowaną przede wszystkim w internecie przez Krajowe Biuro ds. Przeciwdziałania Narkomanii, jest „Krzywo weszło - zmień ustawienia”. Jest to kampania adresowana do ludzi młodych między 16 a 20 rokiem życia i ich rodziców. Jej celem jest propagowanie zdrowego stylu życia bez narkotyków i dopalaczy. Jak mówi dyrektor KBPN:

Dzięki kampanii uda nam się dotrzeć do młodych osób z przekazem, że od ich wiedzy i decyzji zależy ich zdrowie oraz styl życia. Chcielibyśmy, by młodzi ludzie unikali sytuacji lub zdarzeń, w których obecne są narkotyki, a także, żeby w razie konieczności potrafili adekwatnie zareagować chroniąc siebie i swoich znajomych przed możliwymi zagrożeniami. „Zmiana ustawień” oznacza: kieruj tak swoim postępowaniem, by cieszyć się życiem i młodością. Zmieniaj ustawienia na coraz lepsze. (Krzywo weszto - zmień ustawienia 2018)

Warto tu podkreślić, że kampanie medialne w krajach europejskich nie mają udowodnionej skuteczności profilaktycznej w odniesieniu do zapobiegania narkomanii. W artykule poświęconym roli kampanii medialnych w prewencji narkomanii wśród młodych (EMCDDA 2013) stwierdzono, że kampanie z zakresu profilaktyki zdrowia czy bezpieczeństwa drogowego odnoszą zadowalające 
skutki, natomiast te mające na celu przeciwdziałanie narkomanii są mało skuteczne, a mogą być nawet szkodliwe. Oparte najczęściej na naukowych podstawach modelu przekonań zdrowotnych Karen Glanz lub teorii uzasadnionego działania Icka Ajzena, wychodzą z fałszywego założenia, że młodzi ludzie podejmują decyzje o używaniu środków psychoaktywnych na podstawie racjonalnych przesłanek i kalkulacji dotyczących swojego zachowania. Przekazywanie informacji o szkodliwości narkotyków w nikły sposób zmienia postawy młodzieży i normy je kreujące. Natomiast wydaje się, że zachęcanie młodych do poszukiwania osobowych kryteriów pozytywnych zachowań może mieć walor nie tylko edukacyjny, ale i profilaktyczny.

\section{Przykład kampanii profilakłyczno-edukacyjnej: "Bądźmy poszukiwaczami autoryłełu"}

Ogólnopolska Kampania Edukacyjno-Profilaktyczna „Bądźmy poszukiwaczami autorytetu" została wymyślona przez Tomasza $\mathrm{Gu}-$ bałę, prezesa Fundacji Wspomagającej Wychowanie „Archezja” i pełnomocnika wójta gminy Zielonki ds. profilaktyki uzależnień (zob. www.archezja.com). Początkowo jej celem było uczczenie dziesiątej rocznicy śmierci św. Jana Pawła II, ukazanie jego postaci jako autorytetu dla młodzieży oraz zachęcenie dorosłych, by dążyli do wzmacniania swoich kompetencji wychowawczych. Po kilku latach fundacja stworzyła projekt wdrożeniowy, który uzyskał aprobatę i wsparcie Ministerstwa Sprawiedliwości, w związku z czym w listopadzie 2018 roku kampania mogła się rozpocząć. W jej ramach został opracowany pakiet scenariuszy i narzędzi do przeprowadzenia zajęć wychowawczo-profilaktycznych dla dzieci z klas IV-VIII szkół podstawowych i III klas gimnazjum, ich rodziców oraz nauczycieli i wychowawców. Prowadzona jest również strona internetowa $\mathrm{z}$ materiałami bezpośrednio związanymi z kampanią (autorytet.org), a także tworzona jest sieć ambasadorów kampanii w poszczególnych województwach. Co ważne, zajęcia prowadzone $\mathrm{w}$ ramach kampanii każda szkoła może wpisać w harmonogram programu wychowawczo-profilaktycznego (por. Prawo oświatowe 2016). Ponadto prowadzone są badania ewaluacyjne w każdej z grup docelowych oraz bieżące katalogowanie sprawozdań spływających do fundacji na temat realizowanych zajęć. 
Celem kampanii jest rozpoczęcie dyskusji o potrzebie autorytetów w życiu młodych ludzi, szczególnie w wychowaniu i profilaktyce zachowań ryzykownych, wzbudzenie refleksji rodziców i nauczycieli nad swoimi relacjami z dziećmi oraz nauczenie ich, czym różni się autorytet od idola czy celebryty. Twórcy kampanii wychodzą z założenia, że głównymi przyczynami podejmowania zachowań ryzykownych (także antyspołecznych, przestępczych) jest brak mistrzów, będących punktami odniesienia w życiu młodzieży oraz niewłaściwe, głównie autorytarne i permisywne postawy wychowawcze rodziców i nauczycieli.

W kampanii promowana jest postawa autorytetu, mistrza, czyli osoby, która za pomocą wrodzonego i wyuczonego arsenału cech i umiejętności sprawia, że drugi człowiek odnajduje swoją mądrość, pełnię zdrowia psychofizycznego, społecznego i moralno-duchowego. Dzieci uczą się jak takie osoby można rozpoznać, ocenić kto jest autorytetem, jakie ma cechy i w jaki sposób można także w sobie kształtować cechy mistrza. Dorośli z kolei poznają trzy rodzaje relacji wychowawczych i rozmawiają o tym jak rozpoznawać i wspierać potencjały młodych ludzi.

Zajęcia dla młodych ludzi podzielone zostały wedle kryterium wieku. Dla uczniów klas IV-VI przygotowano specjalną układankę z kartami, na których z jednej strony wypisane są cechy autorytetu i idola-celebryty, a z drugiej jest obrazek. Dzieci omawiają i dobierają cechy tak, by całość ułożyła się w obrazek. Zadaniem prowadzącego jest kierunkowanie myślenia dzieci oraz wskazywanie, kto ma jakie cechy. Dla uczniów klas VII-VIII oraz III gimnazjum przygotowane są dwa filmy (do wyboru przez wychowawcę) o treści związanej z kampanią. Tu również realizowana jest debata na temat właściwości autorytetów, kto zasługuje na to miano, a kto nie. Rodzicom dedykowane są trzy filmy na temat stylów wychowawczych, a nauczycielom film pt. „Autorytet, który łączy”, każdy z odpowiednio przygotowanym do tego scenariuszem. Poza tym twórcy kampanii postarali się o atrakcyjne materiały dla szkól: plakaty, ulotki, certyfikaty, a wszystko to w kolorowym, nawiązującym do treści pudełku (zob. autorytet.org).

Do stycznia 2019 roku w projekcie wzięło udział 132000 dzieci i młodzieży, 9328 rodziców i 5784 nauczycieli. Odbiór zajęć w całej Polsce jest bardzo pozytywny. Średnia ocena spotkania ze strony 
dzieci wyniosła 4,65 w skali od 1 do 6, co jest bardzo wysoką oceną dla nieobowiązkowych zajęć edukacyjno-profilaktycznych. Średnia ocen spotkania dla rodziców to 4,8, a ocena od nauczycieli - aż 5,18. Można w związku z tym wnioskować, że przygotowane dla prowadzących zajęcia scenariusze są czytelne, uporządkowane, dobrze zaplanowane, a narzędzia w postaci filmów edukacyjnych oraz układanki i pozostałe materiały uzyskały szeroką aprobatę.

\section{Analiza i interpretacja wybranych danych ewaluacii procesu ogólnopolskiej kampanii „Bq̨ámy poszukiwaczami aułoryłełu”|}

Ewaluacja bezpośrednia miała charakter ilościowy i szerokozakresowy $\mathrm{w}$ formie pretestu i posttestu. W związku z tym wszyscy młodzi ludzie, większość nauczycieli oraz rodziców biorących udział w zajęciach realizowanych w ramach kampanii wypełniali kwestionariusze ankiet internetowych na specjalnie przygotowanej do tego platformie. Skrócone, wybrane wyniki zostaną przedstawione z podziałem grupy na dzieci i młodzież oraz osoby dorosłe w porządku merytorycznym, czyli z podziałem na pięć obszarów: poczucia wsparcia społecznego i relacji, wiedzy o cechach autorytetu, marzeń młodzieży, zachowań ryzykownych i normatywnych oraz oceny zajęć realizowanych w kampanii.

Dzieciom i młodzieży od 7 do 18 roku życia zadano 11 pytań, które dotyczyły: poczucia wsparcia społecznego i relacji interpersonalnych, wiedzy o autorytecie, marzeń młodziėzy, zachowań ryzykownych i normatywnych oraz oceny zajęć zrealizowanych w ramach kampanii.

Nauczycielom i rodzicom zadano pięć pytań, z czego cztery były identyczne $\mathrm{w}$ obydwu kwestionariuszach, co pozwoliło na porównanie perspektyw przyjmowanych przez te dwie grupy. Zabieg ten podyktowany był przede wszystkim chęcią wskazania na konieczność wspólpracy rodziców i nauczycieli, a także realizacją celów szczegółowych projektu, które w obu grupach docelowych osób dorosłych dotyczyły poprawy relacji z dziećmi i młodzieżą.

1 Przedstawione dane zostały zaczerpnięte $\mathrm{z}$ raportu końcowego kampanii. 
Dane $z$ ewaluacji procesu wskazują, że ogromny wpływ na podejmowanie przez młodych ludzi zachowań ryzykownych ma ich poczucie społecznego wsparcia oraz jakość relacji interpersonalnych w najbliższym otoczeniu. Poczucie wsparcia jest związane bezpośrednio z poczuciem bezpieczeństwa, ale też z przywiązaniem do osób znaczących, takich jak rodzice, wychowawcy, przyjaciele czy dalsza rodzina. Travis Hirschi, twórca jednej z ważniejszych teorii kryminologicznych, przyjął tezę, że prawdopodobieństwo zachowań kryminogennych wzrasta wtedy, kiedy więzi społeczne zostaną w jakiś sposób zerwane. Innymi słowy, jednostka może podejmować zachowania ryzykowne, ponieważ nie ma wsparcia społecznego ani pozytywnych relacji z bliskimi osobami (zob. Siemaszko 1993). Hirschi wyróżnił cztery komponenty więzi człowieka $z$ otoczeniem: zaangażowanie i zaabsorbowanie, przekonanie i przywiązanie, które w perspektywie badań ewaluacyjnych wydają się być kluczowe. Przywiązanie bowiem oznacza emocjonalny i uczuciowy związek młodego człowieka $\mathrm{z}$ rodziną, szkołą, grupą rówieśniczą, środowiskiem lokalnym. W procesie tworzenia i trwania tych związków (relacji) kształtuje się wewnętrzna kontrola społeczna, czyli tak zwane superego albo sumienie. To z kolei staje się najważniejszym kryterium wyboru tego, co dobre i tego, co złe. Człowiek kierujący się sumieniem (superego) potrafi odróżnić czyn zgodny z prawem od niezgodnego, a jeśli popełni błąd (wykroczenie, przestępstwo), pojawia się u niego poczucie winy. Staje się ono naturalnym motywatorem do zmiany na lepsze albo do pracy nad mechanizmami obronnymi i przyjmowaniem łatwych do zdiagnozowania technik neutralizacji, które opisali w swojej teorii neutralizacji amerykańscy kryminolodzy Gresham M. Sykes i David Matza (1957). Kształtowanie sumienia (superego) przyczynia się więc do minimalizowania zachowań ryzykownych, a jeśli takowe wystąpią, człowiek ma wówczas zdecydowanie lepsze perspektywy naprawcze i resocjalizacyjne.

Aby sprawdzić elementarny poziom przywiązania, wsparcia społecznego i relacji interpersonalnych dzieci i młodzieży, zadano im pytania dotyczące wyboru osób, z którymi mogą porozmawiać, do których mają zaufanie, szczególnie w trudnych sprawach. Poczucie, że jest na świecie taka osoba, stanowi dla nich niewątpliwie ważny czynnik chroniący. Młodzi respondenci zadeklarowali w około 70\%, że mają taką osobę. Większy odsetek dziewcząt niż chłopców 
deklaruje, że ma z kim porozmawiać, co jest informacją, że chłopcy mogą być bardziej narażeni na niebezpieczeństwa. $Z$ badań wynika, że największe poczucie wsparcia mają uczniowie klas ósmych, a najmniejsze uczniowie klas czwartych. Niepokojąca jest informacja, że niemal $20 \%$ młodzieży deklaruje, iż nie ma z kim porozmawiać. Znaczyłoby to, że co czwarty uczeń szkoły podstawowej nie ma poczucia wsparcia $\mathrm{w}$ najbliższym otoczeniu, a $\mathrm{w}$ trudnych chwilach swojego życia może być pozostawiony samemu sobie, co może stwarzać ryzyko podejmowania zachowań internalizacyjnych czy wręcz autoagresywnych.

Warto też wspomnieć, że największe zaufanie badani uczniowie mają do matek (86\%) i ojców (68,4 \%). Ufają też babci $(46,9 \%)$, co potwierdzają badania Szymona Grzelaka (2015), oraz przyjaciołom, co wskazuje na pozytywne postrzeganie przyjaźni młodzieńczej oraz konieczności wspierania rówieśniczych inicjatyw, w tym liderskich programów profilaktycznych. Niepokojącą informacją jest, że tylko 13\% młodzieży zadeklarowało zaufanie do wychowawcy szkolnego, co jest niemal równoznaczne z zaufaniem do kuzynów, cioć i wujków. Warto przyjrzeć się tym wynikom, szczególnie z perspektywy grona pedagogicznego, które ma niewątpliwy wplyw na klimat szkolny, stanowiący ważny czynnik determinujący zachowania ryzykowne (Ostaszewski 2014).

Twórcy kampanii uznali, że ważne jest to nie tylko, by poszukiwać mądrych mistrzów życia, ale też, by samemu dążyć do cech wskazujących na dojrzałą osobowość. Zaproponowano więc uczniom zestaw cech charakterystycznych dla autorytetu i takich, które autorytet może mieć, ale nie są one konieczne, by nim być. Młodzi w preteście wybrali przede wszystkim takie cechy jak: sprawiedliwy, rozsądny, odpowiedzialny, mądry, uczciwy i umiarkowany. Najwięcej głosów padło na: uczciwy i mądry, co pokazuje, że młodzież ma rozeznanie we właściwościach autorytetu. Porównując dane przed i po zajęciach, można stwierdzić, że wiedza o cechach autorytetu zmieniła się o 7\%. Największą zmianę (wzrost wiedzy) zaobserwowano u dzieci młodszych, z klas czwartych i piątych, z którymi przeprowadzano warsztaty $\mathrm{z}$ wykorzystaniem układanki z cechami mistrza i idola. Warto przypomnieć, że autorytet to nie tylko wieloznaczne pojęcie swoistego zjawiska społecznego, osobowy typ idealny, wzór do naśladowania, matryca wiedzy i mądrości, lecz także o soba, która 
za pomocą wrodzonego i wyuczonego arsenału cech i umiejętności sprawia, że drugi człowiek odnajduje swoją mądrość oraz pełnię zdrowia i życia psychicznego, społecznego i duchowego.

Jeśli chodzi o marzenia młodych ludzi, stanowią one wskaźnik dla pracy pedagogicznej, a w działaniach profilaktycznych (zapobieganie zachowaniom ryzykownym) i prewencyjnych (zapobieganie przestępstwom) obszar ten wydaje się być jednym z najistotniejszych we współpracy z młodzieżą. Tym bardziej, że wiele badań wskazuje na nikłe zmiany na tym polu. Młodzi ludzie marzą przede wszystkim o tym, by kochać i być kochanym (odpowiedź: znalezienie miłości w preteście - 58\% i postteście - 61\%), mieć przyjaciół (w preteście $53 \%$ i $57 \% \mathrm{w}$ postteście) i udaną rodzinę (50\% w preteście i 52\% w postteście). Mniej niż 30\% młodzieży marzy o zdobyciu majątku, zrobieniu kariery, posiadaniu ciekawej pracy i spokojnego życia. $\mathrm{Na}-$ tomiast mniej niż 15\% marzy o życiu pełnym rozrywek, sukcesach naukowych i podróżach oraz władzy politycznej.

Marzenia warto rozwijać i uczyć młodzież praktycznych metod ich realizacji. To ogromny temat do badań, pracy dydaktycznej i wychowawczej na każdym poziomie edukacyjnym oraz na większości przedmiotów w szkole. Jest niemal pewne, że gdyby dorośli większą wagę przykładali do marzeń młodych ludzi, ci chętniej podejmowaliby pracę nad sobą i zwiększaniem swojej dojrzałości osobowej, a to z kolei przekładałoby się na mniejszą ilość zachowań ryzykownych.

Jednym $z$ celów kampanii było rozbudzenie refleksyjności rodzicielskiej nad własną postawą wychowawczą, z zaznaczeniem tej właściwej i najlepiej budującej dojrzałość osobową dzieci i młodzieży o mocnej podbudowie aksjologicznej. W odniesieniu do nauczycieli zaś dążono do skierowania ich uwagi na potencjał młodego pokolenia oraz ugruntowania kadry pedagogicznej w postawie autorytetu. Scenariusze zajęć skierowane do obu grup dorosłych różniły się w przekazie i doborze narzędzi, co zdeterminowało też zróżnicowanie pytań ewaluacyjnych kampanii.

W czasie spotkania rodzice mogli obejrzeć trzy filmy, które obrazują trzy typy relacji wychowawczej. W kwestionariuszu ankiety zostali oni zapytani, którą postawę najczęściej stosują wobec własnych dzieci. Nauczyciele zaś, najczęściej już bez oglądania filmów o postawach, odpowiadali na to samo pytanie. Przyjęto bowiem, że nauczyciele mają podstawową teoretyczną wiedzę z zakresu postaw 
wychowawczych, która jest wpisana w programy studiów i szkoleń pedagogicznych przygotowujących do pracy z młodzieżą.

Około 70\% rodziców oceniło, że przyjmują w relacjach z dzieckiem postawę mistrza, czyli równoważą kontrolę z zaufaniem, starają się w pozytywny sposób motywować dziecko do działań i obowiązków szkolnych, także w życzliwy sposób przyjmują porażki potomka, zachęcając go do dalszej pracy nad sobą. 22\% rodziców oceniło swoje relacje jako obojętne, co sprowadza się do nikłego zainteresowania się dzieckiem, zwracania uwagi głównie na swoje potrzeby oraz zostawiania dziecku pełnej, nieograniczonej swobody w podejmowaniu decyzji. Badania naukowe wskazują, że taka postawa rodzicielska prowadzi do szeregu zachowań ryzykownych ich dzieci, przede wszystkim zaś do braku poczucia bezpieczeństwa i zagubienia w sferze aksjonormatywnej. Według teorii percepcji środowiska rodzinnego Freda Streita (zob. Ulman 2011), młodzież, której rodzice preferują obojętny typ relacji, najczęściej sięga po środki zmieniające świadomość, zaburzające zdolności poznawcze oraz silnie oddziałujące na zmysły (np. LSD, pochodne konopi indyjskich oraz inne tzw. halucynogeny). Obojętni rodzice, nie mając kontroli nad dzieckiem, przyczyniają się do podejmowania przez młodego człowieka szeregu zachowań antyspołecznych. Pozostała grupa badanych rodziców (8\%) określiła swoją postawę jako autorytarną, którą w naukach pedagogicznych charakteryzowana jest jako najbardziej niszcząca relacje, wroga i przyczyniająca się do życia w lęku oraz permanentnym stanie zagrożenia. Bezpodstawne ingerowanie w życie dziecka, tłumienie jego trudnych emocji, agresja, wzbudzanie poczucia winy, przewaga kar nad nagrodami, prowadzą w wielu wypadkach do podejmowania zachowań ryzykownych, w tym kryminogennych oraz używania przez dziecko środków tłumiących, takich jak alkohol czy opiaty.

Zajęcia dla nauczycieli skupiały się na omówieniu cech autorytetu $\mathrm{z}$ perspektywy pracy wychowawczej w szkole oraz zachęceniu kadry pedagogicznej do przestrzegania najważniejszej zasady relacji wychowawczej, która brzmi: „Patrz w dobro i potencjalność młodzieży". Wykorzystano tu autorski film edukacyjny o wymownym tytule Autorytet, który tączy. Nadrzędnym celem bowiem było wskazanie na najistotniejszą cechę autorytetu, a mianowicie zdolność jednoczenia oraz integrowania ludzi o najbardziej odmiennych poglądach. W tej 
grupie aż 88\% respondentów oceniło swoje relacje $\mathrm{z}$ uczniami jako demokratyczne i zrównoważone, w których dorosły jest wspierającym i zachęcającym do pracy mistrzem, 10\% przyjmowało postawę obojętną, a tylko 2\% badanych deklarowało, że są wobec uczniów tyranami. Trudno ocenić perspektywę samooceniających swoje relacje nauczycieli, którzy mają świadomość i wiedzę jak powinno wyglądać komunikowanie się z uczniami. Warto jednak zauważyć, że uzyskane wyniki stanowią wstęp do dalszej pracy badawczej, która powinna przyjąć charakter jakościowy, w nurcie paradygmatu humanistyczno-interpretatywnego.

$\mathrm{Z}$ badań kampanii wynika, że 83\% rodziców i aż 91\% nauczycieli zostało zachęconych do pracy nad sobą, co stanowi zdecydowaną większość badanych. Liczby te pokazują, że wychowawcy mają potrzebę samokształcenia i samowychowania w kierunku dojrzałej osobowości i zrównoważonej postawy wobec wychowanków. Można przypuszczać, ̇̇e respondenci po realizacji kampanii sięgną po literaturę naukową, poradniki oraz inne materiały przybliżające im tematykę związaną z autorytetami. Tylko 13\% rodziców i 7\% nauczycieli stwierdziło, że trudno im ocenić, czy zajęcia wzbudziły ich autorefleksję nad postawami autorytetu, a 4\% rodziców i $2 \%$ nauczycieli oceniło, że zajęcia nie przyczyniły się do jakiejkolwiek zmiany.

Piąte pytanie skierowane tylko do nauczycieli odnosiło się do postrzegania uczniów przez nauczycieli. Deklarowali oni, że bardzo często patrzą na pozytywne cechy uczniów i starają się jak najczęściej zwracać uwagę na pozytywny potencjał młodych ludzi. Warto zauważyć, że 88\% nauczycieli uważało, iż są autorytetami dla swoich uczniów, a 84\% badanych twierdziło, że zawsze (36\%) i bardzo często (48\%) dostrzega potencjały swoich wychowanków. Można więc uznać, że odpowiedzi są spójne, ponieważ postawa autorytetu determinuje działania wychowawcze oparte na nagrodach, pochwałach, wzmacnianiu dobrych cech i zachowań zgodnych z moralnymi wartościami. Tylko 1\% respondentów stwierdziło, że rzadko i bardzo rzadko potrafi dostrzec pozytywny potencjał u swoich uczniów.

\section{Wnioski z badań przeprowadzonych w ramach kampanii}

Opublikowano wiele wyników badań na temat tego, co jest skuteczne w przeciwdziałaniu zagrożeniom społecznym, a co nie jest. 
Odpowiedź na to pytanie jest $z$ jednej strony bardzo trudna, bo wynika $\mathrm{z}$ założenia, że nie jesteśmy $\mathrm{w}$ stanie do końca przewiedzieć zachowań ludzkich. $Z$ drugiej strony wiemy, że człowiek jest istotą psychofizyczną, społeczną, ale przede wszystkim duchową, aksjologiczną, potrzebującą norm i wartości, kierującą się normami i wartościami. Te zaś kształtujemy w sobie przede wszystkim w relacjach z innymi ludźmi. Dlatego, jak wskazuje literatura przedmiotu, kształtowanie przekonań normatywnych jest jedną z najskuteczniejszych metod zapobiegania zachowaniom ryzykownym, ale wydaje się, że bardziej skuteczne jest opieranie się na wartościowych relacjach $\mathrm{z}$ autorytetami i mistrzami.

W przekazie dla pedagogów i nauczycieli twórcy kampanii starali się wskazać, że tylko w relacji wychowawczej opartej na właściwie pojętym autorytecie można kształtować pozytywne przekonania normatywne dzieci i młodzieży. Mogą dotyczyć one dobrych zachowań młodych ludzi, ich zainteresowań czy potrzeb. Warto podkreślić, co potwierdzają badania Szymona Grzelaka oraz te przeprowadzone w ramach kampanii (opublikowane w Raporcie Końcowym Kampanii), że zdecydowana większość młodych ludzi nie podejmuje zachowań ryzykownych i rozwija się normatywnie.

Zdecydowana większość rodziców biorących udział w kampanii uznała, że zajęcia były potrzebne i miały charakter aktywizujący w kierunku poszerzania wiedzy oraz umiejętności stawania się lepszym autorytetem dla dziecka. Rodzice otrzymali podstawowe informacje o najbardziej powszechnych stylach wychowania, co skłoniło ich do refleksji na temat własnej relacji z dzieckiem.

Wysokie oceny prowadzonych zajęć dla młodzieży oraz wskazanie na konieczność bezpośrednich relacji z najbliższymi osobami, które są dla młodych osób autorytetami, wskazuje na ich zaangażowanie $\mathrm{w}$ tematykę kampanii. Uczniowie klas IV-VI dowiedzieli się o kluczowych cechach autorytetu w opozycji do cech idoli i celebrytów. Starsi zaś, poznając właściwości autorytetu, mogli podyskutować nad znaczeniem mistrza w ich życiu. Badania ewaluacji procesu pokazały, że specyfika kampanii profilaktyczno-edukacyjnych jako formy profilaktyki uniwersalnej polega przede wszystkim na właściwym, dostosowanym do odbiorcy doborze przekazywanych treści, ugruntowanych w teoriach i koncepcjach psychopedagogicznych. 


\section{Bibliografia}

Grzelak S. (red.). (2015). Vademecum skutecznej profilaktyki, Warszawa: Ośrodek Rozwoju Edukacji.

Jankowiak B. (2017). Zachowania ryzykowne wspótczesnej mtodzieży. Studium teoretyczno-empiryczne, Poznań: Uniwersytet im. Adama Mickiewicza.

Mrazek P.J.,Haggerty R.J. (1994). New directions in definitions, [w:] P.J. Mrazek, R.J. Haggerty (red.), Reducing risks for mental disorders: Frontiers for preventive intervention research, Washington: National Academy Press, s. 19-29.

Ostaszewski K. (2014). Zachowania ryzykowne mtodzieży w perspektywie mechanizmów resilience, Warszawa: Instytut Psychiatrii i Neurologii w Warszawie.

Siemaszko A. (1993). Granice tolerancji. O teoriach zachowań dewiacyjnych, Warszawa: Wydawnictwo Naukowe PWN.

Sykes G.M., Matza D. (1957). Techniques of neutralization: A theory of delinquency, „American Sociological Review”, t. 22, s. 77-91.

Szymańska J. (2012). Programy profilaktyczne. Podstawy profesjonalnej psychoprofilaktyki, wyd. 3. rozszerzone, Warszawa: Ośrodek Rozwoju Edukacji.

Ulman P. (2011). Spoteczne i rodzinne uwarunkowania uzależnien u dzieci i mtodzieży, „Kwartalnik Naukowy Fides et Ratio”, t. 8, nr 4, s. 74-87.

Wojcieszek K. (2013). Optymalizacja profilaktyki problemów alkoholowych. Pedagogiczne implikacje grupowych interwencji krótkoterminowych, Kraków: Wydawnictwo Rubikon.

Wysocka E. (2013). Diagnoza pedagogiczna. Nowe obszary i rozwiazania, Kraków: Oficyna Wydawnicza „Impuls”.

\section{Netografia}

EMCDDA.(2013). Mass media campaigns for the prevention of drug use in young people, <http://www.emcdda.europa.eu/attachements.cfm/att_212357_ EN_EMCDDA_POD_2013_Mass\%2520media\%2520campaigns. pdf> [dostęp: 18.06.2019].

Krzywo weszto - zmień ustawienia. (2018). <https://kampaniespoleczne.pl/ krzywo-weszlo-zmien-ustawienia/> [dostęp: 15.06.2019].

PARPA. (2019). <https://www.parpa.pl/index.php/profilaktyka-system-rekomendacji/kampanie-profilaktyczno-edukacyjne> [dostęp: 16.06.2019].

Prawo oświatowe. (2016). <http://prawo.sejm.gov.pl/isap.nsf/DocDetails. xsp?id=WDU20170000059> [dostęp: 18.06.2019].

www.archezja.com

www.autorytet.org

www.programyrekomendowane.pl 


\author{
ADRES DO KORESPONDENCJI \\ Dr Karolina Kmiecik-Jusięga \\ Akademia Ignatianum w Krakowie \\ Wydział Pedagogiczny \\ e-mail: karolina.kmiecik-jusiega@ignatianum.edu.pl
}

